\title{
Models as a Medium in Architecture
}

\author{
Atli Magnus Seelow \\ Chalmers University of Technology, Department of Architecture and Civil Engineering \\ Correspondence: Sven Hultins Gata 6, 41296 Gothenburg, Sweden \\ atli.seelow@chalmers.se; Tel.: +46-72-968-8885
}

\begin{abstract}
Architecture is more than just buildings. Its associated production and reception processes take place through a variety of different media. Among those media, the model is of special significance: because architecture, like almost every science or art, works with models as representationally or theoretically simplified images mediating between the abstract and the reality. The properties that characterise models give them a special significance in architecture-both in the abstract, as well as in the concrete. The following article sketches out the history of the architectural model as a medium in a short tour d'horizon. A special focus is placed on showing the versatility of the model-for design and presentation and as an artefact, teaching resource and research medium. It transmits a specific form of knowledge which can be replaced by no other medium.
\end{abstract}

Keywords: history of architecture; architectural models; architectural media

\section{Introduction}

Architecture is more than just buildings. Its associated production and reception processes take place through a variety of different media. The duality of construction and media is a central feature of architecture and knowledge of this duality is as old as the discipline itself (Sonne 2011, pp. 7-14). Vitruvius already distinguishes between that which is signified and that which signifies ('quod significatur et quod significat'). He not only specifies three types of graphic representation-ichnographia, orthographia and scaenographia ('plan', 'elevation' and 'perspective'), which an architect has to master, but also claims that he requires linguistic, mathematical and even musical knowledge (Vitruvius 1960, pp. 5-16).

Among the media, in addition to the drawing, the model has a special significance: because architecture, like almost every science or art, works with models as representationally or theoretically simplified images mediating between the abstract and the reality. The three properties that characterise models generally, namely representation, simplification and non-unique assignment capability (Stachowiak 1973, pp. 131-133), give models special significance in architecture-both in the abstract, as well as in the concrete. This is particularly evident in the concrete architecture model. It shares two essential properties with an actual building-three-dimensionality and materiality - and can therefore often be viewed as its substitute. Furthermore, it also has the ability of making its anticipatory function visible not only in abstracto, but also directly, "at a glance" (Oechslin 2011, p. 131).

The following article sketches out the history of the architectural model as a medium in a short tour d'horizon. A special focus will be placed on showing the versatility of the model-as a design and presentation medium, as an artefact, a teaching resource and a research medium. It transmits a specific form of knowledge which can be replaced by no other medium. In this context it is interesting to note that among the more or less important studies produced so far, concerning media in architecture generally (Frascari, Hale, and Starkey 2007) as well as individual media (e.g. Feldhaus 1953; Nerdinger 1986; Damisch 1994; Sachsse 1997; Forty 2000; Nerdinger 2000), the model has been given the least consideration (Janke 1962; Moon 2005; Morris 2006). This has also been repeatedly emphasized at the recent meetings and exhibitions held on this subject (Modelle und 
Architektur 2009; Modernism in Miniature 2011; Das Architekturmodell 2012). It is all the more surprising, as in other disciplines the model has been accorded growing importance (de Chadarevian and Hopwood 2004; Dirks and Knobloch 2008; Reichle et al. 2008).

\section{Drawing and Model}

Up until the 13th century the design and construction process is determined by the original scale and especially by the ground plan drawings - the calibration of the foundations on the location plane. Three-dimensional plastic representations of buildings and structures are only verified by written sources, such as the wax model of the monastery church of Saint Germain in Auxerre (9th century) described in a report of the Benedictine monk Heiric of Auxerre (Binding and Linscheid-Burdich 2002, pp. 73-99). Although votive or patron models are common as symbolic representations they have but little practical significance.

The architectural model arises in tandem with the development of architectural drawing in the late Middle Ages and the Renaissance-here reference could be made to the drawings in the sketchbook of Villard de Honnecourt from around 1230 (Bechmann 1991).

From the 14th century onwards, to the south of the Alps largescale experimental and presentation models made of wax, clay, wood or brick are created for larger church construction projects in the context of the emerging system of design competition (Millon and Lampugnani 1994; Lepik 1994). For example, for the construction of the cathedral of Santa Maria del Fiore in Florence (1296-1379/1418-1434) numerous partial models are made, first by Arnolfo di Cambio and later by Filippo Brunelleschi, the inventor of vanishing point perspective, for presentation as well as for testing the dome construction. And for St Peter's Basilica in Rome (1506-1626), not only can the entire design and planning process be traced in detail on the basis of drawings of the participating architects-Donato Bramante, Antonio da Sangallo, Baldassare Peruzzi, Michelangelo Buonarroti, Giacomo Barozzi da Vignola, Carlo Maderno and Gian Lorenzo Bernini-, but a number of models are also produced. Sangallo, for instance, has over a period of seven years a detailed, $736 \mathrm{~cm}$ long and $468 \mathrm{~cm}$ high approachable wooden model in scale $1: 30$ built, that would, however, be discarded by Michelangelo (Bredekamp 2008).

In parallel to this the drawing and the model are also theoretically defined. However, the model is accorded only a subordinate function, while the drawing is considered the primary design medium. In De re aedificatoria (1452) Leon Battista Alberti describes architecture primarily as the result of the work with sketches ('lineamenta') and structures ('structura'). There he prefers orthogonal projections, i.e. the floor plan and elevation, and rejects the perspective as a tool for painters because of its inaccurate angles and scale (Alberti 1485; cf. Kieven 2011). Alberti introduces the model at the beginning of the second book - at the transition from design to construction-as a tool for quality assurance:

"I therefore always highly commend the ancient Custom of Builders, who not only in Draughts and Paintings, but in real Models of Wood or other Substance, examin'd and weigh'd over and over again, with the Advice of Men of the best Experience, the whole Work and the Admeasurements of all its Parts, before they put themselves to the Expence or Trouble. By making a Model you will have an Opportunity, thoroughly to weigh and consider the Form and Situation of your Platform with respect to the Region, .... And there you may easily and freely add, retrench, alter, renew, and in short change every Thing from one End to t'other, till all and every one of the Parts are just as you would have them, and without Fault (Alberti 1955, pp. 22)."

As further evidence of the character of the model as an aid device, Alberti does not attach great importance to its implementation:

"I must not omit to observe, that the making of curious, polish'd Models, with the Delicacy of Painting, is not required from an Architect that only designs to shew the real Thing itself; .... For this reason I would not have the Models too exactly finish'd, nor too delicate and neat, but plain and 
simple, more to be admired for the Contrivance of the Inventor, than the Hand of the Workman (Alberti 1955, pp. 22.)"

The primacy of the drawing vis-à-vis the model is evident in the concept of disegno by Giorgio Vasari. On the one hand, it symbolises the draft or design as an intellectual concept, which gives form to the preceding artistic idea in the three arts of painting, sculpture and architecture. But on the other hand disegno also very practically means a drawing (from Latin 'designare', to describe, draw, produce outlines of), which is used to organise work in the workshop and as a means of communication with clients (Vasari 1568; cf. Kemp 1974). In this context, major importance is attached to the interpretation of the Vitruvian representations. Daniele Barbaro changes scaenographia to sciographia ('section'); and Andrea Palladio in I quattro libri dell'architettura elevates the trio of floor plan, elevation and section to a principle of architecture (Palladio 1570).

The model, however, is considered a peripheral instrument. For example, Vincenzo Scamozzi, in L'idea della architettura universale consigned it to the "instruments which serve the architect" ('Stromenti, che servono all'Architetto', Scamozzi 1615, p. 49 ff.).

Nevertheless, in the 16th century the model concept expands considerably in philosophy and mathematics, as can be seen from a discussion between Alessandro Piccolomini and Francesco Barozzi. It becomes recognised that models can facilitate access by laymen or children to abstract or mathematical insights since, as Werner Oechslin puts it, "all forms of abstraction (including the design itself) remain connected with the material and can be explained with reference to it ('ex subiecta materia', Oechslin 2011, p. 133)."

This pedagogical and didactic value which is rooted in the physical visibility of models, what is "modellable", continues to the present day and leads in the 19th century, among other things, to didactically conceived children's toys, such as halfsection models or model building blocks (Oechslin 2011, p. 135-141).

In the course of the 17th and 18th centuries the model advances in practice and theory to a medium that is regarded as a complement to the drawing and gradually as its equal. It gains in importance in baroque architecture, as the graphic representation of its plastic and spatial reification-including optical illusions and perspective foreshortening-presents a major challenge (Kieven 2011, pp. 15-31), which can, however, be more clearly visualised in the model (Mosser 1981; Reuther 1981). Balthasar Neumann, for example, prefers the model to the drawing and whenever possible has three-dimensional objects prepared (Muth 1987).

In the first volume of his Ausführliche Anleitung zur Bürgerlichen Bau-Kunst (1744-1748) Johann Friedrich Penther defines the model as a tool to give concrete form to a design idea:

\footnotetext{
"A model, muster, modello is a physical illustration of a thing to be manufactured or already manufactured, as a house, a fortress, a statue etc. Thus, if the thing is to be made, you can acquire beforehand a complete concept of its shape, or can undertake an improvement in its preparation. They can be made, depending upon the things being modelled, of wood, wax, plaster, cardboard, glue or even of stone pieces; ... (Penther 1744, p. 107)."
}

The frontispiece of the second volume of Ausführliche Anweisung zur Bürgerlichen Bau-Kunst shows an architecture workshop in which putti are working on halfsections of architectural models (Penther 1745, frontispiece; Figure 1). 


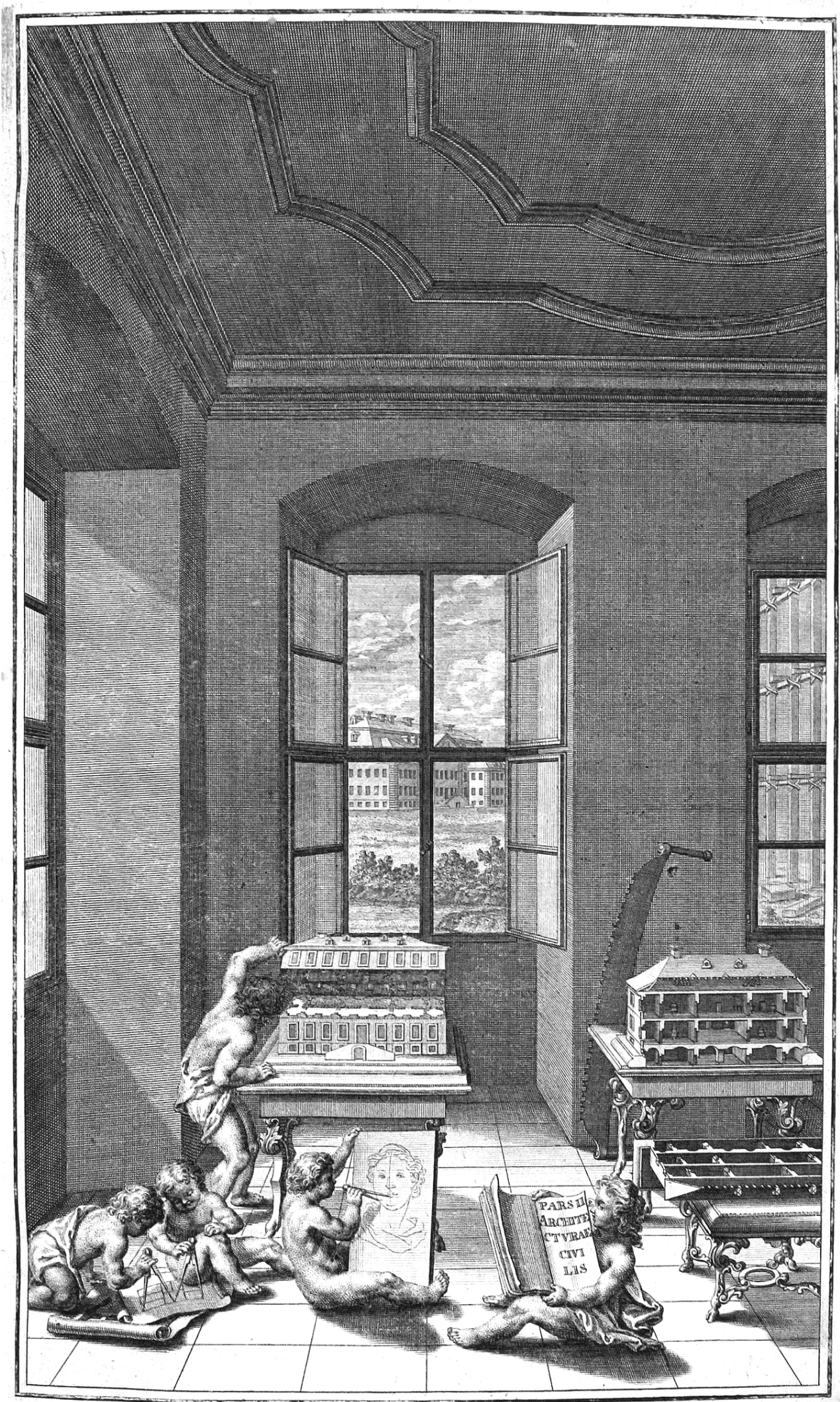

Figure 1. Johann Friedrich Penther, Zweyter Theil der ausführlichen Anleitung zur Bürgerlichen Baukunst, worin durch zwantzig Beyspiele gewiesen, wie die Erfindungen von allerhand Wohn-Gebäuden aus Stein und Holtz ... zu machen, Augsburg 1745-Frontispiece. 


\section{Artefacts and teaching resources}

From the concluding decade of the 18th century architectural models gain further importance as artefacts and objects of study within the context of the Grand Tour. These educational trips are made from the late 16th century onwards by the sons of the European nobility, and later by artists and architects, to Italy and from the middle of the 18th century onwards to Greece, to study the sites and the culture of antiquity and the Renaissance (Wilton and Bignamini 1996). Among the most popular collectors' items on these trips are cork models (phelloplastics) of ancient buildings, as produced above all by the Roman architects Augusto Rosa or Antonio Chichi with great precision and archaeological accuracy. Later, such models are copied by artists north of the Alps as well (Gercke and Zimmermann-Elseify 2001). At a few of the European courts significant model collections are established. The collection of the empress Catherine the Great of Russia includes 34 models by Antonio Chichi.

Cork models serve not only as souvenirs or trophies of an educational trip to Italy or Greece, but they also increasingly take on the function of a teaching or training instrument to convey in physical form the architecture of antiquity and the Renaissance. Individual architects as well as teaching institutions gather large collections of books and drawings, as well as models and plaster casts, to serve as illustrative material for their own work and for educational purposes. One of the largest private collections around 1800 is that of the English architect John Soane. It encompasses, in addition to 7.783 books and around 30.000 drawings (both his own and of others), 252 models. Of these, 118 are models of his own designs, 20 are plaster casts and 14 cork models of ancient Greek and Roman buildings and 100 are models of individual ornamentation and details (Summerson and Dorey 1991, pp. 85-86).

The Architectural Museum of the Technical University of Munich, today the largest architecture collection on the European continent, is an example of the creation of a teaching collection. Carl von Fischer, the first and at the time the only professor of fine architecture at the Academy of Fine Arts in Munich founded in 1808, formulates in his teaching programme that model building needs to be taught and learned in addition to drawing (Nerdinger 2008, pp. 306-309). With the relocation of the training of architects to the polytechnical school founded in 1868 (today the Technical University), the teaching materials for the training of the students-pattern drawings, plaster casts and models - are gathered in a separate collection. To this is added the donation by the Bavarian King Ludwig II of the royal collection of architectural designs, including 45 cork models. The collection remains at the centre of historical architectural training, as it enables a combination of viewing, studying, copying and designing. As in any architectural school or academy the teaching consists mainly of the study of examples on the basis of drawings and models, i. e. original drawings are copied, spaces and proportions studied, and plaster casts and models reproduced (Nerdinger 1993).

Up until the end of the 19th century the role of the architecture model remains limited to that of an artefact, an instrument for teaching and training as well as a medium for visualization in addition to the architectural drawing. In this context it should be noted that at the same time various types of architectural drawing are being developed to imitate the spatial representation of a model. Among them one could mention the axonometric projection developed by Auguste Choisy as well as the architectural drawing using a picturesque perspective perfected by Friedrich von Thiersch among others. In both cases, whether through analytical or picturesque presentation, the ground plan, section and elevation are merged in a spatial representation (Nerdinger 1986, pp. 13-18).

The architecture model as a teaching tool and research medium has become topical again in recent years. For example, in 1971 Jeremy Dixon reconstructed Vladimir Tatlin's Monument to the Third International (1919) in the form of a model for the exhibition Art in Revolution of the London Hayward Gallery (Dixon 2012). Later more model reconstructions of the tower are made for other museums: the Moderna Museet in Stockholm, the Tretyakov Galerie in Moskau, the Musée National d'Art Moderne in the Centre Georges Pompidou as well as the Royal Academy of Arts in London. In the years 1973-1996 Friedrich Kurrent has students at the Technical University of Munich build both actually real as well as unrealised 20th-century houses - mainly by Adolf Loos and Le Corbusier-in the form of models (Kurrent 1995; Kurrent 1997; Kurrent 1998). And in 2014-2015 students at the 
Chalmers University of Technology in Gothenburg reconstruct the Stockholm Exhibition 1930 of Arts and Crafts and Home Industries ('Stockholmsutställningen 1930 av konstindustri, konsthantverk och hemslöjd') by building the pavillons designed by Gunnar Asplund and other Swedish architects in the form of models (Seelow 2016).

\section{Photo models and building blocks}

In the first decades of the 20th century the picturesque architectural drawings of the late 19th century are increasingly replaced by axonometric projections and architectural models. The latter in particular gain greatly in significance as a modern design and presentation medium.

In the course of the modernization and objectification of design and presentation media by the protagonists of the modern movement the axonometric projection becomes preferred; it is to communicate a "new technical objectivity in architecture". Walter Gropius even advocates this at the Bauhaus as "representation technology conforming to the spirit of the age" (Nerdinger 1986, pp. 1718), although it is introduced as early as the 18th century by Johann Friedrich Penther and described as "horizontal section" (Penther 1744, pp. 17-21).

The triumphal march of the architecture model is furthered, firstly, by the availability of modern photographic and printing techniques, such as image reproduction in offset printing from 1910 onwards. These enable for the first time the realistic reproduction of photographed architecture models in the mass media (Elser 2012, pp. 13-14). One of the most interesting examples is Ludwig Mies van der Rohe's study for a glass highrise building (1922), which he creates in connection with his famous competition entry for a highrise building on Friedrichstrasse in Berlin (1921). As he himself writes, he studies the "rich play of light reflections" on the glass facade of the model in order to determine the shape of the building and its floor plan. He later publishes numerous photographs, drawings and collages of this model, including in 1924 on the title page of the avantgarde magazine G. Material zur elementaren Gestaltung (Mies van der Rohe 1922, pp. 122-124; Mies van der Rohe 1924, p. 9; cf. Neumann 2001, pp. 186-189; Lepik 2001, pp. 325-328).

Secondly, the architectural model serves to represent the rationalisation efforts - standardization, prefabrication and mass production-employed by a number of the protagonists of the modern movement (cf. Bittner 1995). In 1923 Walter Gropius, for example, presents for the first time a "modular system in large scale": a modular housing system (Gropius 1924, p. 8; Gropius 1926, pp. 25-30), which "could be put together in various combinations ..., somewhat similar to Anker Blocks on a large scale" (Nerdinger 1985, p. 15, Note 62). He refers here to the Anker building blocks produced since 1882 as a toy for children. Later he demonstrates the thoroughly rationalised planning and construction process of the housing estate of Dessau-Törten (1926-1928) in publications with axonometric drawings or models-both showing the stepbystep production process by very similar modelling methods (Gropius 1930, pp. 161, 165).

In contrast, Ernst May presents at the exhibition Die Wohnung of Deutscher Werkbund in Stuttgart Weissenhof (1927) on the test site a halfsection experimental house that-just as in the case of a model-demonstrates its prefabricated (modular design) construction (Rasch and Rasch 1928, p. 101; cf. Kirsch 1989, pp. 30-31). Uno Åhrén later does the same at the Stockholm Exhibition 1930 with his halfsectioned rowhouse (Seelow 2016, pp. 156-161). 


\section{5. “The miniature boom"}

In the 1930s new technologies give impetus to the further professionalisation of model construction. Models become increasingly used to display comprehensive future designs and placed in scenarios with the photographic and cinematic possibilities of the time. For instance, at the 1939 World Exhibition in New York, the city of the future is presented in the form of large-scale models such as Futurama by Norman Bel Geddes and the City of Tomorrow exhibition (Herman 2012, pp. 58$65)$.

Here the model undergoes a fundamental change. It is no longer the imitation of a building, but becomes itself a building, as Jane Jacobs describes in her essay "The miniature boom" (1958). Models are no longer exclusively built of cardboard, wood or plaster by architecture offices through laborious manual work. Increasingly professional model workshops enter the picture, using specialized machines, which are able to create complex designs and components in series in materials such as synthetics or aluminium (Jacobs 1958, pp. 106-111, 196).

The rapid development of model construction displaces to a large extent the perspective drawing for presentation and design. The work of Mies van der Rohe after his emigration to Chicago can be mentioned as an example of this: He uses models, collages and photo montages predominantly for presentation purposes, and pure perspective drawings significantly less. In his architecture office the model building department led from 1944 by Edward Duckett occupies up to onequarter of the floor space. And hardly any other architect of this time has himself photographed as often with models of his designs as does Mies van der Rohe (Lambert 2001, pp. 204-217, 569-570). The photos of architects and models, published so extensively from the 1960s onwards in the press, promote the conception of the architect as an almost omnipotent planner, who with his models not only shapes individual buildings but even whole cities.

The perfecting of model building goes so far that in 1975 Arthur Drexler expresses suspicion, in conjunction with the exhibition The Architecture of the École des Beaux Arts, that models show an ideal state compared to which the real building is doomed to failure. The architects of modernism have exalted their models to sculptures and lost sight of reality; the building stands in an interesting but ultimately superfluous relationship to the model (Drexler 1977, p. 27).

\section{The model as art and research medium}

The perfecting of modelbuilding techniques opens new fields for the model ranging from a free art object to various forms of models as a medium for research.

In 1976, as a response to Drexler's previously mentioned Beaux Arts exhibition, the exhibition Idea as Model is organized at the Institute for Architecture and Urban Studies in New York. There 20 architectural models are exhibited, which show in a rather abstract way their connection to real projects and can be described as objects of art, for which there is demand on the art market (Frampton 1981). Peter Eisenman explains in this context that "models, like drawings, can easily lead their own conceptual lives, relatively independent of the project which they represent (Eisenman 1981, p. 1)."

Working with models also leads to various forms of studies and research models, some of which even play a decisive role in the design process. For example, at Frei Otto's Institute for Lightweight Structures, in the two special research areas "Lightweight Construction" and "Natural Construction", many different types of models are used as a research medium-"thinking in models" -, not only to create a form, but also to analyse construction principles and for the determination of forces and force vectors: including textile models and soap film models for tent and membrane constructions, chains and pendant models for lattice shell constructions and finally soap bubbles or liquid threads in the case of pneumatic or branched structures (Barthel 2005, pp. 16-30; Graefe 2005, pp. 70-78; Weber 2012, pp. 45-50; Vrachliotis 2017). Or in the Office for Metropolitan Architecture in Rotterdam led by Rem Koolhaas models, primarily of blue styrofoam, are used as a basis for collaborative design processes referred to as cadavre exquis (Yaneva 2009). 


\section{Epilogue: Models from the computer-the end of the model?}

With the use of computers in architecture from the 1980s onward a fundamental change begins. Initially, the majority of computerassisted applications are aimed at digitalising conventional design processes. But the development of three-dimensional modelling programs together with CNC-milling, 3D-printers and robots make possible the seamless translation of a virtual model into a physical product. Since in theory the same data can be used for a virtual model as for real production, the difference between the model and reality is to a certain extent eliminated (Schubert 2010, pp. 56-63; Kaufmann 2010, pp. 64-71).

In the digital age the architectural model has often been declared dead. While classical architectural drawing has gradually been dematerialised and displaced by digital media, digital and physical models continue to exist side by side. The physical architectural model even, in all the forms outlined here, has the unique advantage compared to virtual media that-as Piccolomini and Barozzi already point out in 1560-all forms of abstraction are bound to material. Which is why the model will remain indispensable for a long time yet.

\section{References}

1. Alberti, Leon Battista. 1485. De re aedificatoria. Florence.

2. Alberti, Leone Battista. 1955. Ten Books on Architecture. Translated by Cosimo Bartoli and James Leoni, edited by Joseph Rykwert. London: Tiranti.

3. Barthel, Rainer. 2005. Natural Forms - Architectural Forms. In Frei Otto. Complete Works. Lightweight construction, natural design. Edited by Winfried Nerdinger. Basel et al.: Birkhäuser, pp. 16-30. ISBN 3764372338.

4. Bechmann, Roland. 1991. Villard de Honnecourt. La pensée technique au XIIIe siècle et sa communication. Paris: Picard. ISBN 2708403672.

5. Binding, Günther, and Susanne Linscheid-Burdich. 2002. Planen und Bauen im frühen und hohen Mittelalter nach den Schriftquellen bis 1250. Darmstadt: Wissenschaftliche Buchgesellschaft. ISBN 3534154894.

6. Bittner, Regina. 1995. Zukunft aus Amerika. Fordismus in der Zwischenkriegszeit. Dessau: Stiftung Bauhaus Dessau 1995. ISBN 3910022065.

7. Bredekamp, Horst. 2008. Sankt Peter in Rom und das Prinzip der produktiven Zerstörung. Bau und Abbau von Bramante bis Bernini. Berlin: Wagenbach. ISBN 9783803126023.

8. de Chadarevain, Soraya, and Nick Hopwood. 2004. Models. The Third Dimension of Science. Stanford: Writing Science. ISBN 0804739722.

9. Damisch, Hubert. 1994. The Origin of Perspective. Cambridge, Massachusetts: MIT Press. ISBN 0262540770.

10. Das Architekturmodell. Werkzeug, Fetisch, kleine Utopie. The Architectural Model. Tool, Fetish, small Utopia [exhibition catalogue]. 2012. Edited by Oliver Elser and Peter Cachola Schmal. Frankfurt am Main: Deutsches Architekturmuseum. ISBN 9783858813466.

11. (Dirks and Knobloch 2008) Dirks, Ulrich, and Eberhard Knobloch. 2008. Modelle. Frankfurt: Lang. ISBN 9783631553770.

12. Dixon, Jeremy. 2012 Reconstructing Tatlin's Tower. AA Files 64, pp. 37-47.

13. Drexler, Arthur. 1977. Engineer's Architecture. Truth and its Consequences. In The Architecture of the École des Beaux Arts. Edited by Arthur Drexler and Richard Chafee. London: Secker \& Warburg, p. 13-59. ISBN 0436137100 .

14. Eisenman, Peter. 1981. Preface. In Kenneth Frampton, Idea as Model. 23 architects 1976/1980. New York: Rizzoli, p. 1. ISBN 0847803767.

15. Elser, Oliver. 2012. Zur Geschichte des Architekturmodells im 20. Jahrhundert. On the History of the Architectural Model in the 20th Century. In Das Architekturmodell. Werkzeug, Fetisch, kleine Utopie. The Architectural Model. Tool, Fetish, small Utopia [exhibition catalogue]. Edited by Oliver Elser and Peter Cachola Schmal. Frankfurt am Main: Deutsches Architekturmuseum, pp. 11-22, ISBN 9783858813466.

16. Feldhaus, Franz Maria. 1953. Geschichte des technischen Zeichnens, Oldenburg: Stalling.

17. Forty, Adrian. 2000. Words and Buildings. A Vocabulary of Modern Architecture, London: Thames and Hudson. ISBN 0500341729.

18. Frampton, Kenneth. 1981. Idea as Model. 23 architects 1976/1980. New York: Rizzoli. ISBN 0847803767. 
19. Frascari, Marco, Jonathan Hale and Bradley Starkey. 2007. From Models to Drawings. Imagination and Representation in Architecture. London: Routledge. ISBN 0415431131.

20. Gercke, Peter, and Nina Zimmermann-Elseify. 2001. Antike Bauten. Korkmodelle von Antonio Chichi 17771782. Kassel: Staatliche Museen Kassel. ISBN 3931787133.

21. Graefe, Rainer. 2005. Where Architecture and Civil Engineering Meet. In Frei Otto. Complete Works. Lightweight construction, natural design. Edited by Winfried Nerdinger. Basel et al.: Birkhäuser, pp. 70-78. ISBN 3764372338.

22. Gropius, Walter. 1924. Wohnhaus-Industrie. In Ein Versuchshaus des Bauhauses in Weimar. Edited by Adolf Meyer. Bauhausbücher 3. Munich: Langen, p. 5-14.

23. Gropius, Walter. 1926. Der große Baukasten, Das neue Frankfurt 2, pp. 25-30.

24. Gropius, Walter. 1930. Bauhausbauten Dessau. Bauhausbücher 12. Munich: Langen.

25. Herman, Arthur. 2012. Freedom's Forge. How American Business Produced Victory in World War II, New York: Random House. ISBN 1400069645.

26. Jacobs, Jane. 1958. The miniature boom, Architectural Forum, May 1958, pp. 106-111, 196.

27. Janke, Rolf. 1962. Architekturmodelle. Stuttgart: Hatje.

28. Kaufmann, Stefan. 2010. Die Realisierung des Unvorstellbaren. In Wendepunkte im Bauen. Von der seriellen zur digitalen Architektur. Edited by Winfried Nerdinger. Munich: Detail. Institut für Internationale Architekturdokumentation, pp. 64-71, ISBN 9783920034393.

29. Kemp, Wolfgang. 1974. Disegno. Beiträge zur Geschichte des Begriffs zwischen 1547 und 1607. Marburger Jahrbuch für Kunstwissenschaft, pp. 219-240.

30. Kieven, Elisabeth. 2011. Architekturzeichnung. Akademische Entwicklungen in Rom um 1700. In Die Medien der Architektur. Edited by Wolfgang Sonne. Munich: Deutscher Kunstverlag, pp. 15-31. ISBN 9783422068216.

31. Kirsch, Karin. 1987. Die Weißenhofsiedlung. Werkbund-Ausstellung 'Die Wohnung' - Stuttgart 1927. Stuttgart: Deutsche Verlags Anstalt. ISBN 3421028818.

32. Kurrent, Friedrich. 1995. Raummodelle. Wohnhäuser des 20. Jahrhunderts. Salzburg and Munich: Pustet. ISBN 3702503471.

33. Kurrent, Friedrich. 1997. Le Corbusier, 1887-1965. 40 Wohnhäuser. Bauten und Projekte von Le Corbusier. Salzburg: Pustet. ISBN 3702503560.

34. Kurrent, Friedrich. 1998. Adolf Loos 1870-1933. 40 Wohnhäuser. 40 Houses. Bauten und Projekte von Adolf Loos. Salzburg: Pustet. ISBN 3702503803.

35. Lambert, Phyllis. 2001. Mies Immersion. In Mies in America. Edited by Phyllis Lambert. Montréal: Canadian Centre for Architecture, pp. 192-589.

36. Lepik, Andres. 1994. Das Architekturmodell in Italien. 1335-1550. Worms: Werner. ISBN 3884621041.

37. Lepik, Anders. 2001. Mies und die Photomontage. In Mies in Berlin. Ludwig Mies van der Rohe. Die Berliner Jahre 1907-1938. Edited by Terence Riley and Barry Bergdoll. London and New York: The Museum of Modern Art New York, pp. 325-328. ISBN 0870700189.

38. Mies van der Rohe, Ludwig. 1922. Hochhäuser. Frühlicht, pp. 122-124;

39. Mies van der Rohe, Ludwig. 1924. Hochhäuser. G. Material zur elementaren Gestaltung, 3, June 1924, title page [p. 9].

40. Millon, Henry A., and Vittorio Magnago Lampugnani. 1994. The Renaissance from Brunelleschi to Michelangelo. The Representation of Architecture. London: Thames and Hudson. ISBN 0500341303.

41. Modelle und Architektur. 2009. Internationales Kolloquium. Munich: Architekturmuseum der Technischen Universität München. 6-8 November 2009.

42. Modernism in Miniature. Points of View [exhibition]. 2012. Montréal: Canadian Centre for Architecture, 22 September 2011 to 8 January 2012.

43. Moon, Karen. 2005. Modeling Messages. The Architect and the Model. New York: Monacelli Press. ISBN 1580931286.

44. Morris, Mark. 2006. Models. Architecture and the Miniature, Chichester: Wiley. ISBN 9780470015926.

45. Mosser, Monique. 1981. Französische Architekturmodelle im Zeitalter der Aufklärung. Models of French architecture in the Age of Enlightenment. Daidalos, 2, 1981, pp. 83-97.

46. Muth, Hanswernfried. 1987. Aus Balthasar Neumanns Baubüro. Pläne der Sammlung Eckert zu Bauten des großen Barockarchitekten. Würzburg: Echter. ISBN 3429010373. 
47. Nerdinger, Winfried. 1985. Walter Gropius - Vom Amerikanismus zur Neuen Welt. In Der Architekt Walter Gropius. Berlin: Gebr. Mann, pp. 9-28. ISBN 378611448.

48. Nerdinger, Winfried. 1986. Die Architekturzeichnung. Vom barocken Idealplan zur Axonometrie. Munich: Prestel. ISBN 3791307215.

49. Nerdinger, Winfried. 1993. Architekturschule München. 1868-1993. 125 Jahre Technische Universität München. Munich: Klinkhardt und Biermann. ISBN 3781403505.

50. Nerdinger, Winfried. 2007. Architektur wie sie im Buche steht. Salzburg: Pustet. ISBN 3702505504.

51. Nerdinger, Winfried. 2008. Die Bauschule an der Akademie der Bildenden Künste München 1809-1873. In 200 Jahre Akademie der Bildenden Künste München. Edited by Nikolaus Gerhart, Walter Grasskamp and Florian Matzner. Munich: Hirmer, pp. 306-337. ISBN 9783777442051.

52. Neumann, Dietrich. 2001. Hochhaus aus Glas. In Mies in Berlin. Ludwig Mies van der Rohe. Die Berliner Jahre 1907-1938. Edited by Terence Riley and Barry Bergdoll. London and New York: The Museum of Modern Art New York, pp. 186-189. ISBN 0870700189.

53. Oechslin, Werner. 2011. Architekturmodell. 'Idea materialis'. In Die Medien der Architektur. Edited by Wolfgang Sonne. Munich: Deutscher Kunstverlag, pp. 131-156. ISBN 9783422068216.

54. Palladio, Andrea. 1570. I quattro libri dell'architettura. Venice.

55. Penther, Johann Friedrich. 1744-1748. Ausführliche Anleitung zur Bürgerlichen Bau-Kunst I-IV. Augsburg.

56. Rasch, Heinz and Bodo. 1928. Wie Bauen? Materialien und Konstruktionen für industrielle Produktion. Jahres-Ausgabe 1928. Stuttgart.

57. Reichle, Ingeborg, Steffen Siegel, and Achim Spelten. 2008. Visuelle Modelle. Munich: Fink. ISBN 9783770546329.

58. Reuther, Hans. 1981. Wesen und Wandel des Architekturmodells in Deutschland. Origin and development of the Architectural Model in Germany, Daidalos, 2, pp. 98-110.

59. Sachsse, Rolf. 1997. Bild und Bau. Zur Nutzung technischer Medien beim Entwerfen von Architektur. Braunschweig: Vieweg. ISBN 3528061138.

60. Scamozzi, Vincenzo. 1615. L'idea della architettura universale. Venice.

61. Schubert, Gerhard. 2010. Individuelle Industrieform. Computereinsatz in der Planung. In Wendepunkte im Bauen. Von der seriellen zur digitalen Architektur. Edited by Winfried Nerdinger. Munich: Detail. Institut für Internationale Architekturdokumentation, pp. 56-63, ISBN 9783920034393.

62. Seelow, Atli Magnus. 2016. Reconstructing the Stockholm Exhibition 1930. Stockholmsutställningen 1930 rekonstruerad. Stockholm: Arkitektur Förlag. ISBN 9789186050948.

63. Sonne, Wolfgang. 2011. Die Medien der Architektur. In Die Medien der Architektur. Edited by Wolfgang Sonne. Munich: Deutscher Kunstverlag, pp. 7-14. ISBN 9783422068216.

64. Stachowiak, Herbert. 1973. Allgemeine Modelltheorie. Vienna: Springer. ISBN 3211811060

65. Summerson, John, and Helen Dorey. 1991. A New Description of Sir John Soane's Museum. London: The Trustees.

66. Vasari, Giorgio. 1568. Le vite de' più eccelenti pittori, scultori et architettori. Florence.

67. Vitruvius. 1960. The Ten Books on Architecture. Translated by Morris Hicky Morgan. Cambridge, Massachusetts, 1914; Reprint 1960 New York: Dover Publications.

68. Vrachliotis, Georg. 2017. Denken in Modellen. In Frei Otto. Denken in Modellen. Edited by Georg Vrachliotis, Joachim Kleinmanns, Martin Kunz and Philip Kurz. Leipzig: Spector Books, pp. 22-32. ISBN 9783959050753.

69. Weber, Christiane. 2010. Frei Otto. Experimentelle Modelle. In Das Architekturmodell. Werkzeug, Fetisch, kleine Utopie. The Architectural Model. Tool, Fetish, small Utopia [exhibition catalogue]. Edited by Oliver Elser and Peter Cachola Schmal. Frankfurt am Main: Deutsches Architekturmuseum, pp. 45-50, ISBN 9783858813466.

70. Wilton, Andrew, and Ilaria Bignamini. 1996. Grand Tour. The Lure of Italy in the Eighteenth Century. London: Tate Gallery Publications. ISBN 1854371886.

71. Yaneva, Albena. 2009. Made by the Office for Metropolitan Architecture. An Ethnography of Design. Rotterdam: 010 Publications. 